\title{
EFFECTS OF LOW TEMPERATURE ON TWO CYANOBACTERIA
}

\author{
D. KUMAR, * J. B. SINGH, AND H. D. KUMAR \\ Department of Botany, Banaras Hindu University, Varanasi-221005, India
}

(Received January 6, 1992)

The effects of low-temperature $\left(0^{\circ} \mathrm{C}\right)$ incubation on nitrogenase-catalyzed acetylene reduction, alkaline phosphatase activity and cellular ATP pool(s) have been studied in Nostoc linckia and Nostoc muscorum. The cultures incubated at $0^{\circ} \mathrm{C}$ showed higher enzymatic activities than those incubated at $25^{\circ} \mathrm{C}$ but the ATP content was lower at $0^{\circ} \mathrm{C}$. Our experiments with chloramphenicol and rifampicin suggest that de novo protein synthesis is required for nitrogenase, but not for alkaline phosphatase even at low temperature. The increase in alkaline phosphatase activity at $0^{\circ} \mathrm{C}$ may possibly be due to enhanced catalytic activity of this enzyme. The ability to protect enzyme activities at $0^{\circ} \mathrm{C}$ implies that $N$. linckia and Nostoc muscorum may be tolerant to low-temperature cellular damage.

The effect of temperature on metabolic processes is well established (11) and follows a general pattern of increasing metabolic rate with increasing temperatures. The susceptibility to low temperatures varies greatly from organism to organism and depends on growth temperature. Some plants are highly susceptible to chilling temperature (18) while some bacteria are markedly sensitive; some of them even die when exposed to low temperature near $0^{\circ} \mathrm{C}(19,22)$.

Cyanobacteria are procaryotic organisms, but also share the property of oxygenic photosynthesis characteristically found in eukaryotic algae and higher plants. They seem to represent an evolutionary link between bacteria and plants. The study on the effect of low temperature (near $0^{\circ} \mathrm{C}$ ) on cyanobacteria could therefore increase our understanding of the mechanism of the chilling susceptibility of higher plants and cold shock of bacteria. Cyanobacteria are frequently exposed to alternating freeze-thaw cycles during the early spring and late fall seasons in temperate regions. However, the question of how cyanobacteria respond to freezing has received little attention. Ono and Murata (21) investigated the effects of chilling on photosynthetic activities of Anacystis nidulans. When the algal cells

* Address reprint requests to: Dr. D. Kumar, Department of Botany, Banaras Hindu University, Varanasi-221005, India. 
are exposed to low temperatures, the viability of cells declines (23), the photosynthetic $\mathrm{O}_{2}$-evolution, the electron transport and the phosphorylation diminish $(7,12$, 23 ) and the light absorption spectrum of carotenoid changes (3). Glutamate and pteridines are released from the cells $(7,12)$ and the cytoplasmic membrane and the thylakoid membranes are morphologically altered (4) at low temperatures.

The effects of freezing have been studied only with nitrogenase extract preparations $(5,8,28)$ and in vivo only with terrestrial cyanobacteria (6). There have been no reports describing the effects of low temperature (near $0^{\circ} \mathrm{C}$ ) on in vivo nitrogenase and alkaline phosphatase activities in mesophilic cyanobacteria. The present study deals with the effect of low-temperature $\left(0^{\circ} \mathrm{C}\right)$ incubation on in vivo nitrogenase and alkaline phosphatase activities and cellular ATP content of Nostoc linckia and Nostoc muscorum.

\section{MATERIALS AND METHODS}

Nostoc linckia and $N$. muscorum were grown axenically in an inorganic medium free from combined nitrogen (1), at a temperature of $25 \pm 1^{\circ} \mathrm{C}$ in aerated $\left(15-20 \mathrm{ml} \mathrm{min}^{-1}\right)$ culture tubes. Culture bath was illuminated with four F36T12/ $\mathrm{D} / \mathrm{HO}$ fluorescent lamps on either side of the bath at an average intensity of 300 $\mu \mathrm{E} \mathrm{m}^{-2} \mathrm{~s}^{-1}$. The growth was measured turbidimetrically in a Bausch and Lomb Spectronic-20 colorimeter at $660 \mathrm{~nm}$. Dry weight and chlorophyll $a$ were determined as described earlier (13).

Nitrogenase activity was measured by the acetylene-ethylene assay utilizing the nitrogenase-catalyzed conversion of acetylene to ethylene (27). The suspensions of $2 \mathrm{ml}$ of whole cell cultures were placed into $8 \mathrm{ml}$ rubber-stoppered vacutainer tubes containing $90 \%$ air $+10 \% \mathrm{C}_{2} \mathrm{H}_{2}$ and placed in the shaker bath having facility for low-temperature $\left(0^{\circ} \mathrm{C}\right)$ incubation. Ethylene was measured by injection of $0.5 \mathrm{ml}$ of the gas-phase into an CIC-gas chromatograph fitted with R-Porapak column. $\mathrm{N}_{2}$ at $40 \mathrm{ml} \mathrm{min}^{-1}$ was used as the carrier gas.

Alkaline phosphatase activity was estimated by the method of Ihlenfeldt and Gibson (10). Culture $(4 \mathrm{ml})$ was centrifuged and treated with toluene $(2 \% \mathrm{v} / \mathrm{v})$. To this, $4.0 \mathrm{ml}$ of Tris- $\mathrm{HCl}$ buffer $(0.2 \mathrm{M} ; \mathrm{pH} 8.2)$ was added and equilibrated for 10 min at $37^{\circ} \mathrm{C}$ in waterbath. The reaction was started by the addition of $0.2 \mathrm{ml}$ of p-nitrophenyl phosphate $(100 \mathrm{~mm})$ and incubated for $30 \mathrm{~min}$ at $37^{\circ} \mathrm{C}$. The reaction was terminated by the addition of $0.2 \mathrm{ml}$ of $1 \mathrm{M} \mathrm{K} \mathrm{K}_{2} \mathrm{HPO}_{4}$. The liberated yellowcolored $p$-nitrophenol was measured at $420 \mathrm{~nm}$. Specific activity was expressed as nmol $p$-nitrophenol min $^{-1} \mathrm{mg}$ protein ${ }^{-1}$. Cellular ATP content was extracted using $4 \%$ trichloroacetic acid (TCA) and $2 \mathrm{~mm}$ EDTA by the method of Larsson and Olsson (15). ATP content was estimated by luciferine-luciferase assay method using LKB-1250 luminometer. 


\section{RESULTS AND DISCUSSION}

Actively nitrogen-fixing cultures of Nostoc linckia and N. muscorum showed about 5 to $6 \%$ of heterocysts frequency and generation time of $25 \mathrm{~h}$ and $22 \mathrm{~h}$, respectively. The cellular nitrogenase activities found in $N$. linckia and $N$. muscorum were 65 and $124 \mathrm{nmol} \mathrm{C}_{2} \mathrm{H}_{4} \mathrm{mg}$ dry $\mathrm{wt}^{-1} \mathrm{~h}^{-1}$, respectively. However, when these cultures were incubated in the dark, a significant decrease in the activity was observed (Figs. 1, 2).

N. linckia and $N$. muscorum incubated at $0^{\circ} \mathrm{C}$ under light showed 60 and 68 nmol $\mathrm{C}_{2} \mathrm{H}_{4}$ formed $\mathrm{mg}$ dry $\mathrm{wt}^{-1} \mathrm{~h}^{-1}$, respectively. This activity was almost comparable to the control value at $25^{\circ} \mathrm{C}$ in $N$. linckia. However, $N$. muscorum showed about $45 \%$ less activity than the control value. When these cultures were incubated in dark at $0^{\circ} \mathrm{C}, N$. linckia and $N$. muscorum showed an enhancement of about $95 \%$ and $45 \%$ of nitrogenase activity over control dark values at $25^{\circ} \mathrm{C}$ (Figs. $1,2)$. Glucose $(1 \%)$ stimulated nitrogenase activity in the dark-incubated cultures of both the strains. However, cultures incubated at $0^{\circ} \mathrm{C}$ when supplemented with

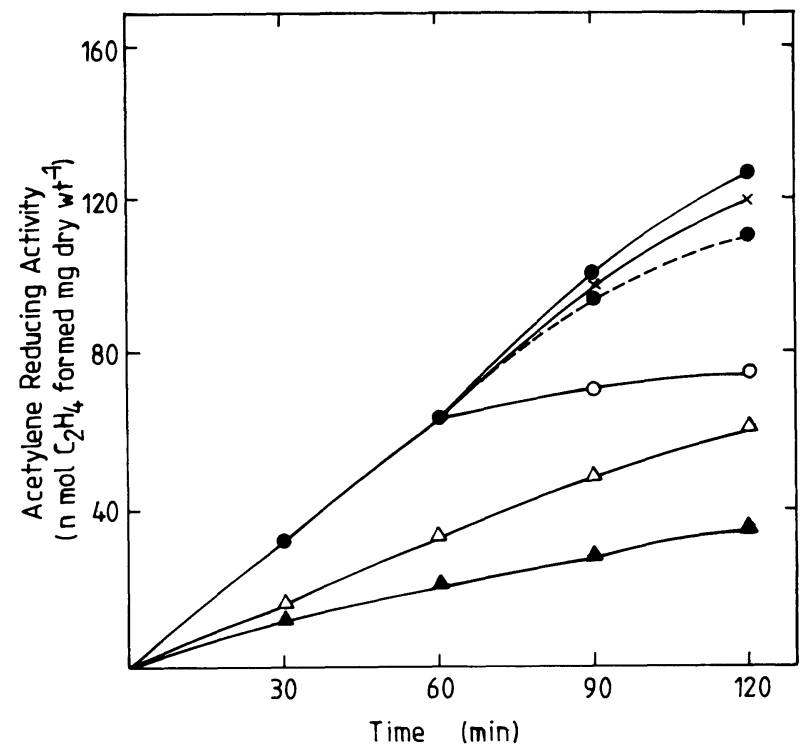

Fig. 1. Effect of low-temperature treatment on nitrogenase (acetylene reducing) activity of Nostoc linckia. Cultures were grown under nitrogen-fixing condition at $25^{\circ} \mathrm{C}$ in a light intensity of $300 \mu \mathrm{E} \mathrm{m}^{-2} \mathrm{~s}^{-1}$. For this experiment, exponentially grown cultures were divided into three sets. First set was incubated under light $(\bullet-\bullet)$; second was incubated under dark $(\boldsymbol{\Delta})$; third set was incubated under dark spiked with $1 \%$ glucose $(\triangle)$. After $60 \mathrm{~min}$, the light-incubated sample was divided into three sets and incubated under different indicated experimental conditions: Chloramphenicol $(50 \mu \mathrm{g}$ $\left.\mathrm{ml}^{-1}\right)$ or rifampicin $\left(25 \mu \mathrm{g} \mathrm{ml}^{-1}\right)$ at $25^{\circ} \mathrm{C}$ under dark or light $(\bigcirc)$; Dark, $0^{\circ} \mathrm{C}(\bullet--\bullet)$; Light, $0^{\circ} \mathrm{C}(\times)$. Incubation and assay were performed at respective temperatures. 


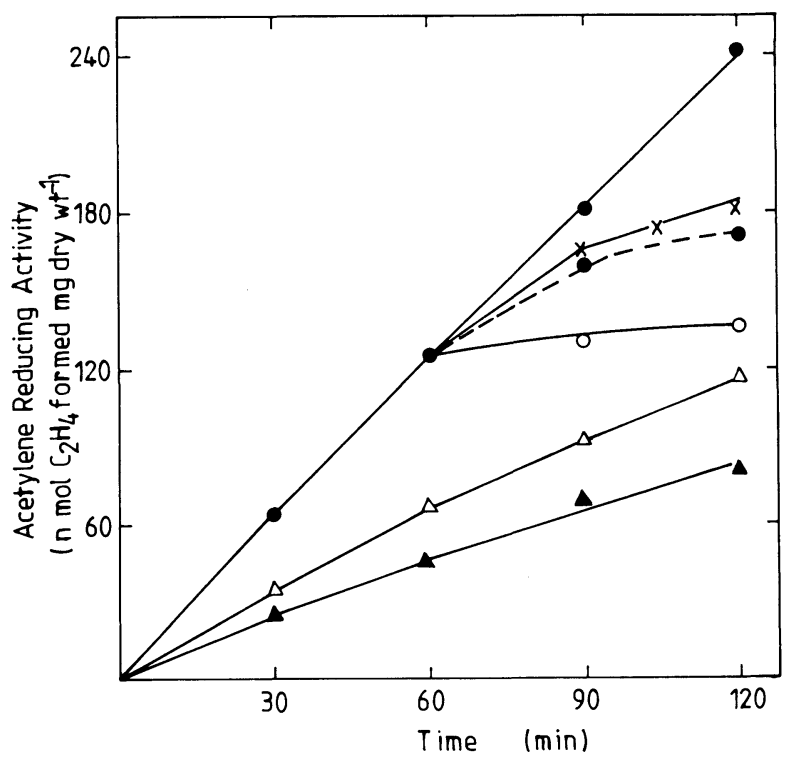

Fig. 2. Effect of low-temperature treatment on nitrogenase (acetylene reducing) activity of Nostoc muscorum. Experimental conditions are the same as Fig. 1.

Table 1. Effect of preillumination and chloramphenicol on acetylene reducing activity at $0{ }^{\circ} \mathrm{C}$ of Nostoc linckia and Nostoc muscorum. Cultures were grown to exponential phase under $300 \mu \mathrm{E} \mathrm{m}^{-2} \mathrm{~s}^{-1}$ light intensity at $25^{\circ} \mathrm{C}$.

\begin{tabular}{lcc}
\hline Condition & \multicolumn{2}{c}{$\begin{array}{c}\text { Acetylene reducing activity } \\
\left(\mathrm{nmol} \mathrm{C}_{2} \mathrm{H}_{4} \mathrm{mg} \mathrm{dry} \mathrm{wt}^{-1} 5 \mathrm{~h}^{-1}\right)\end{array}$} \\
\cline { 2 - 3 } & Nostoc linckia & Nostoc muscorum \\
\hline Light, $25^{\circ} \mathrm{C}$ & 300 & 500 \\
Dark, $25^{\circ} \mathrm{C}$ & 70 & 140 \\
$0^{\circ} \mathrm{C}$, light & 250 & 200 \\
$* 0^{\circ} \mathrm{C}$, light & 100 & 165 \\
$* 0^{\circ} \mathrm{C}+$ glucose $(1 \%)$, light & 180 & 234 \\
$0^{\circ} \mathrm{C}$, chloramphenicol $\left(50 \mu \mathrm{g} \mathrm{ml}^{-1}\right)$, light & 25 & 40 \\
\hline
\end{tabular}

* Samples of $0^{\circ} \mathrm{C}$ and $0^{\circ} \mathrm{C}+$ glucose $(1 \%)$ were darkened at $25^{\circ} \mathrm{C}$ for $5 \mathrm{~h}$ before acetylene addition. Other sets were incubated and assayed under indicated experimental conditions.

either chloramphenicol $\left(50 \mu \mathrm{g} \mathrm{ml}^{-1}\right)$ or rifampicin $\left(25 \mu \mathrm{g} \mathrm{ml}^{-1}\right)$ showed less acetylene reducing activity after an hour (Figs. 1,2) and there was no increase in the activity even after $3 \mathrm{~h}$ of treatment. Addition of chloramphenicol and rifampicin alone indicates the involvement of de novo protein synthesis in the enhancement of nitrogenase activity at $0^{\circ} \mathrm{C}$.

To test whether light has any effect on the nitrogenase activity of the cultures incubated at $0^{\circ} \mathrm{C}$, samples were darkened for $5 \mathrm{~h}$ at $25^{\circ} \mathrm{C}$ and then incubated and assayed for acetylene reducing activity at $0^{\circ} \mathrm{C}$ (Table 1). Cultures of both the 
strains incubated at either $0^{\circ} \mathrm{C}$ or at $25^{\circ} \mathrm{C}$ in presence of light exhibited higher nitrogenase activity in comparison to dark-incubated cultures. Furthermore, addition of glucose $(1 \%)$ stimulated the nitrogenase activity of the darkened samples. Chloramphenicol supplementation inhibited the nitrogenase activity of both the strains.

Nitrogenase is generally inactivated at temperatures around $0^{\circ} \mathrm{C}$. It appears that it may be the Fe-protein which exhibits greatest sensitivity to cold as well as to $\mathrm{O}_{2}$. Dua and Burris (5) reported an inactivation of approximately $85 \%$ nitrogenase of crude extracts from Clostridium at low temperatures. However, cold lability varies from organism to organism as, even in pure state, the Fe-protein of Klebsiella pneumoniae nitrogenase is insensitive to the cold. Zumft and Mortenson (28) have suggested the possibility of structural changes in the ferredoxin protein component of bacterial nitrogenase. In the present study, high rates of nitrogenase activity were detected in low-temperature-incubated cultures. This implies that nitrogenase is capable of surviving at low temperatures. However, de novo synthesis of nitrogenase or other critical proteins is required at low-temperature incubations.

Prefreezing conditions (light or dark) and the glucose experiment indicate that photosynthetic products (carbohydrates) have a major impact on the nitrogenase activity during low temperatures. The light pretreatment would increase the potential for storage of carbon compounds whereas the dark pretreatment would promote the utilization of stored carbon compounds. Many reports have shown that freeze protection can be afforded by carbohydrates $(17,25)$, organic acids $(24)$, amino acids (9). The storage of organic compounds may raise cell's osmotic potential and hence play an important role in low-temperature protection. This study shows that glucose addition has a beneficial effect on nitrogenase activity of the low-temperature $\left(0^{\circ} \mathrm{C}\right)$-incubated cultures.

The ATP requirement for nitrogenase activity in cyanobacteria is normally supplied by photophosphorylation (26) and possibly by oxidative phosphorylation (16). Utilization of stored carbon compounds (under dark conditions) can supply energy for nitrogenase and other enzymes. Subsequently, we assayed total cellular

Table 2. ATP content of Nostoc linckia and Nostoc muscorum under different experimental conditions. ATP content was expressed as nmol ATP mg Chl $a^{-1}$. Cultures were grown under nitrogen-fixing conditions at $25^{\circ} \mathrm{C}$ and $300 \mu \mathrm{E} \mathrm{m}^{-2} \mathrm{~s}^{-1}$ light intensity.

Incubations were performed for $5 \mathrm{~h}$ at respective temperatures $(0$ and $25^{\circ} \mathrm{C}$ ) and then the ATP content was measured.

\begin{tabular}{|c|c|c|c|c|}
\hline \multirow{2}{*}{ Condition } & \multicolumn{2}{|c|}{ Nostoc linckia } & \multicolumn{2}{|c|}{ Nostoc muscorum } \\
\hline & $0^{\circ} \mathrm{C}$ & $25^{\circ} \mathrm{C}$ & $0^{\circ} \mathrm{C}$ & $25^{\circ} \mathrm{C}$ \\
\hline Light & 579 & 662 & 305 & 317 \\
\hline Dark & 350 & 250 & 300 & 309 \\
\hline Dark + glucose $(1 \%)$ & 420 & 345 & 332 & 347 \\
\hline Dark + chloramphenicol $\left(50 \mu \mathrm{g} \mathrm{ml}^{-1}\right)$ & 345 & 217 & 253 & 267 \\
\hline Dark + rifampicin $\left(25 \mu \mathrm{g} \mathrm{ml}^{-1}\right)$ & 333 & 200 & 271 & 250 \\
\hline
\end{tabular}


Table 3. Alkaline phosphatase activity of test organisms under different conditions. Cultures were grown under phosphate-starved conditions for $24 \mathrm{~h}$ and then incubated for $5 \mathrm{~h}$ at respective temperatures $\left(0\right.$ and $\left.25^{\circ} \mathrm{C}\right)$. Alkaline phosphatase activity was assayed at $37^{\circ} \mathrm{C}$ of all samples.

\begin{tabular}{lcccc}
\hline \multirow{2}{*}{ Condition } & \multicolumn{4}{c}{$\begin{array}{c}\text { Alkaline phosphatase activity } \\
\left(\text { nmol PNP }^{a} \text { min }^{-1} \mathrm{mg}_{\text {protein }}{ }^{-1}\right)\end{array}$} \\
\cline { 2 - 5 } & \multicolumn{3}{c}{ Nostoc linckia } & \multicolumn{2}{c}{ Nostoc muscorum } \\
& $0^{\circ} \mathrm{C}$ & $25^{\circ} \mathrm{C}$ & $0^{\circ} \mathrm{C}$ & $25^{\circ} \mathrm{C}$ \\
\hline Light & 22.0 & 17.5 & 8.5 & 7.9 \\
Dark & 21.2 & 17.3 & 7.8 & 6.8 \\
Glucose $(50 \mathrm{mM})$ & 15.5 & 10.5 & 8.3 & 5.8 \\
Chloramphenicol $\left(50 \mu \mathrm{g} \mathrm{ml}^{-1}\right)$ & 19.8 & 17.2 & 8.0 & 5.1 \\
Rifampicin $\left(25 \mu \mathrm{g} \mathrm{m}^{-1}\right)$ & 21.8 & 17.7 & 7.0 & 6.0 \\
\hline
\end{tabular}

a PNP: $p$-Nitrophenol.

ATP content of both the cultures under different conditions (Table 2). Lighttransferred cultures of both the test organisms showed higher ATP content at $25^{\circ} \mathrm{C}$ than those at $0^{\circ} \mathrm{C}$. However, there was a marked difference $(14 \%)$ in the ATP content of light-incubated cultures of $N$. linckia at both temperatures. Darkincubated cultures had lower ATP content than light-incubated cultures of both the strains. Addition of glucose (1\%) to dark-incubated cultures of either of the two strains showed a remarkable change in the ATP content with respect to temperature (Table 2). It is seen from Table 2 that $N$. linckia showed higher ATP content at $0^{\circ} \mathrm{C}$ and $N$. muscorum showed it at $25^{\circ} \mathrm{C}$ in dark-incubated cultures. ATP content of dark-incubated, glucose-supplemented cultures of $N$. muscorum was even higher than light-grown cultures. Chloramphenicol $\left(50 \mu \mathrm{g} \mathrm{ml}^{-1}\right)$ and rifampicin $\left(25 \mu \mathrm{g} \mathrm{ml}^{-1}\right)$ treatments had no effect on ATP content of both the strains. Although the studies by Bottomley and Stewart (2), Mullineaux et al. (20) and Kumar (14) suggested that ATP supply does not limit nitrogen fixation in vivo, it is not yet clear whether the supply of ATP or of reductant primarily controls the activity of dark nitrogen fixation in cyanobacteria. Our experiment indicates that it is not ATP content but rather the reductant which plays an important role at low-temperature incubation.

Table 3 shows the alkaline phosphatase activity of the test organisms incubated at $0^{\circ} \mathrm{C}$ and $25^{\circ} \mathrm{C}$ under various conditions. Light had no effect on alkaline phosphatase activity of any of the strains. However, low-temperature incubation $\left(0^{\circ} \mathrm{C}\right)$ showed higher enzyme activity. Chloramphenicol and rifampicin treatment produced no effect, suggesting that no fresh protein for alkaline phosphatase is synthesized during the low-temperature treatment. The increase in alkaline phosphatase activity during low-temperature incubation may possible be due to enhanced catalytic activity of enzyme.

The ability of the test organisms to protect both nitrogenase and alkaline phosphatase enzymes at $0^{\circ} \mathrm{C}$ suggests that $N$. linckia and $N$. muscorum may be 
tolerant to low-temperature cellular damage.

D. K. and J. B. S. thank the University Grants Commission for financial help.

\section{REFERENCES}

1) Allen, M. B. and Arnon, D. I., Studies on nitrogen-fixing blue-green algae. I. Growth and nitrogen fixation by Anabaena cylindrica Lemm. Plant Physiol., 30, 366-372 (1955).

2) Bottomley, P. J. and Stewart, W. D. P., ATP and nitrogenase activity in nitrogen-fixing heterocysts from Anabaena variabilis (ATCC 29413). Biochim. Biophys. Acta, 723, 83-90 (1977).

3) Brand, J. J., Spectral changes in Anacystis nidulans induced by chilling. Plant Physiol., 59, 970973 (1977).

4) Brand, J. J., Spectral changes in membrane fragments and artificial liposomes of Anacystis nidulans induced by chilling. Arch. Biochem. Biophys., 193, 385-391 (1979).

5) Dua, R. D. and Burris, R. H., Stability of nitrogenase enzymes and the reactivation of a cold labile enzyme. Proc. Natl. Acad. Sci. USA, 50, 169-174 (1963).

6) DuBois, J. D. and Kapustika, L. A., Osmotic stress effects on the nitrogenase activity of aquatic cyanobacteria. Aquat. Bot., 11, 11-20 (1981).

7) Forrest, H. S., Van Baalen, C., and Myers, J., Occurrence of pteridines in a blue-green alga. Science, 125, 699-700 (1957).

8) Haystead, A., Robinson, R., and Stewart, W. D. P., Nitrogenase activity in extracts of heterocystous and non-heterocystous blue-green algae. Arch. Microbiol., 74, 235-243 (1970).

9) Heber, U., Tyankova, L., and Santarius, K. A., Stabilization and inactivation of biological membranes during freezing in the presence of amino acids. Biochim. Biophys. Acta, 241, 587-592 (1971).

10) Ihlenfeldt, M. J. A. and Gibson, J., Phosphate utilization and alkaline phosphatase activity in Anacystis nidulans (Synechococcus). Arch. Microbiol., 102, 23-28 (1975).

11) Jacobes, R. and Lind, O., The combined relationship of temperature and molybdenum concentration to nitrogen fixation by A. cylindrica. Microbial Ecol., 3, 205-217 (1977).

12) Jansz, E. R. and Maclean, F. I., The effects of cold shock on the blue-green alga Anacystis nidulans. Can. J. Microbiol., 19, 381-387 (1973).

13) Kumar, D., Effect of light quality on the acetylene reducing activity of the isolated heterocysts of Anabaena sp. strain CA. J. Gen. Appl. Microbiol., 35, 369-375 (1989).

14) Kumar, D. and Kumar, H. D., Protection of nitrogenase levels in dark-incubated cultures of Anabaena sp. strain CA by various carbon sources and restoration of nitrogenase activity by oxygen. Br. Phycol. J., 25, 251-256 (1990).

15 ) Larsson, C. M. and Olsson, T., Firefly assay of adenine nucleotides from algae: Comparison of extraction methods. Plant Cell Physiol., 20, 145-155 (1979).

16) Lex, M. and Stewart, W. D. P., Algal nitrogenase, reductant pool(s) and photosystem I activity. Biochim. Biophys. Acta, 292, 436-443 (1973).

17) Lineberger, R. D. and Staponkus, P. L., Cryoprotection by glucose, sucrose and raffinose to chloroplast thylakoids. Plant Physiol., 65, 298-304 (1980).

18) Lyons, J. M., Chilling injury to the plants. Annu. Rev. Plant Physiol., 24, 445-466 (1973).

19) Meynell, G. C., The effect of sudden chilling on E. coli. J. Gen. Microbiol., 19, 380-389 (1953).

20) Mullineaux, P. M., Chaplin, A. E., and Gallon, J. R., Effects of light to dark transition on carbon reserves, nitrogen fixation and ATP concentrations in cultures of Gloeocapsa sp. 1430. J. Gen. Microbiol., 120, 227-232 (1980).

21) Ono, T. A. and Murata, N., Chilling susceptibility of the blue-green alga Anacystis nidulans. II. Stimulation of the passive permeability of cytoplasmic membrane at chilling temperature. Plant Physiol., 67, 182-187 (1981). 
22) Paton, J. B., McMurachie, E. J., May, B. K., and Elliott, W. H., Effect of growth temperature on membrane fatty acid composition and susceptibility to cold shock of Bacillus amyloliquifaciens. J. Bacteriol., 135, 754-759 (1978).

23) Rao, V. S. K., Brand, J., and Myers, J., Cold shock syndrome in Anacystis nidulans. Plant Physiol., 59, 965-969 (1977).

24) Santarius, K. A., The effects of freezing on thylakoid membranes in the presence of organic acids. Plant Physiol., 48, 156-162 (1971).

25) Santarius, K. A., The protective effect of sugars on chloroplasts membranes during temperature and water stress and its relationship to frost, desiccation and heat resistance. Planta, 113, 105-114 (1973).

26) Stewart, W. D. P., Some aspects of structure and function in nitrogen-fixing cyanobacteria. Annu. Rev. Microbiol., 34, 497-536 (1980).

27) Stewart, W. D. P., Fitzgerald, G. P., and Burris, R. H., In situ studies on nitrogen fixation using the acetylene reduction technique. Proc. Natl. Acad. Sci. USA, 58, 2071-2078 (1967).

28) Zumft, W. B. and Mortenson, L. E., The nitrogen-fixing complex of bacteria. Biochim. Biophys. Acta, 416, 1-52 (1975). 